GLYCOTECHNOLOGY 


\title{
GLYCOTECHNOLOGY
}

\author{
edited by \\ E. G. Berger \\ Department of Physiology \\ University of Zurich \\ H. Clausen \\ Department of Oral Diagnostics \\ University of Copenhagen \\ R. D. Cummings \\ Department of Biochemistry \& Molecular Biology \\ University of Oklahoma \\ A Special Issue of \\ GLYCOCONJUGATE JOURNAL \\ Volume 16, No. 2 (1999)

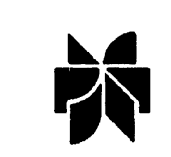 \\ SPRINGER SCIENCE+BUSINESS MEDIA, LLC
}




\section{Glycoconjugate Journal}

VOLUME 16 NUMBER 2 FEBRUARY 1999 ISSN: 0282-0080

SPECIAL GLYCOTECHNOLOGY ISSUE

Guest Editors: Dr. E. G. Berger, University of Zurich

Dr. H. Clausen, University of Copenhagen

Dr. R. D. Cummings, University of Oklahoma

\section{PAPERS}

Eckart Grabenhorst, Peter Schlenke, Susanne Pohl, Manfred Nimtz and Harald S. Conradt

Genetic engineering of recombinant glycoproteins and the glycosylation pathway in mammalian host cells

Marleen Maras, Irma van Die, Roland Contreras and Cees A.M.J.J. van den Hondel

Filamentous fungi as production organisms for glycoproteins of bio-medical interest

Friedrich Altmann, Erika Staudacher, Iain B.H. Wilson and Leopold März

Insect cells as hosts for the expression of recombinant glycoproteins

Martine Malissard, Steffen Zeng and Eric G. Berger

The yeast expression system for recombinant glycosyltransferases

Karl F. Johnson

Synthesis of oligosaccharides by bacterial enzymes

Thomas Bülter and Lothar Elling

Enzymatic synthesis of nucleotide sugars

Beat Ernst and Reinhold Oehrlein

Substrate and donor specificity of glycosyl transferases

Åke P. Elhammer, Ferenc J. Kézdy and Akira Kurosaka

The acceptor specificity of UDP-GalNAc: polypeptide $\mathbf{N}$-acetylgalactosaminyltransferases 


\section{Library of Congress Cataloging-in-Publication Data}

Glycotechnology / edited by E.G. Berger, H. Clausen, R.D. Cummings.

$$
\text { p. } \mathrm{cm} \text {. }
$$

"A special issue of Glycoconjugate journal, volume 16, no. 2 (1999)."

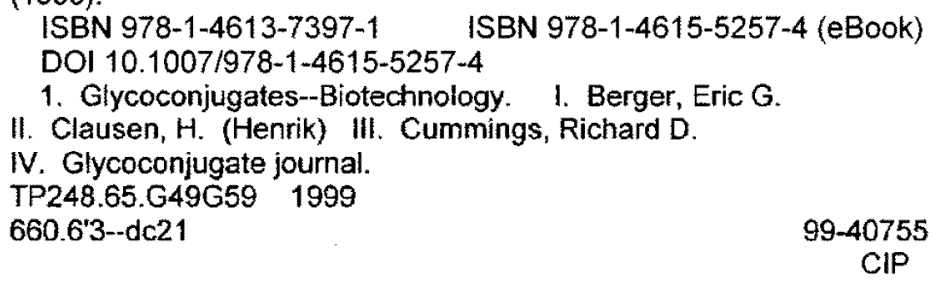

Copyright ( 1999 Springer Science+Business Media New York Originally published by Kluwer Academic Publishers in 1999

Softcover reprint of the hardcover ist edition 1999

All rights reserved. No part of this publication may be reproduced, stored in a retrieval system or transmitted in any form or by any means, mechanical, photocopying, recording, or otherwise, without the prior written permission of the publisher, Springer Science+Business Media, LLC

Printed on acid-free paper. 